\title{
Cirrhotic Ascites: Impact of Designed Nursing Care Protocol on Minimizing Complications of Cirrhotic Ascites
}

\author{
Shaimaa Sayed Mohamed, Aml M. Ahmed, Youssif Ismail \& Jehan Abdel Rehem. \\ B.Sc. Nursing, Medical-Surgical Nursing, Faculty of Nursing, Mania University, Egypt. \\ Assistant Professor of Adult Nursing, Medical-Surgical Nursing, Department, Faculty of Nursing, Assiut University, \\ Egypt. \\ Professor of Internal Medicine, internal medicine, Faculty of Department Medicine, , Mania, University, Egypt. \\ Lecturer of Medical Surgical Nursing, Medical-Surgical Nursing, Faculty of Nursing, Mania University, Egypt.
}

\begin{abstract}
Cirrhotic ascites is the most complications among cirrhotic patients .The Aim of the study: To identify the effect of the designed nursing protocol on minimizing complications of cirrhotic ascites. Quasi-Experimental research design was utilized in this study .This study was conducted in the internal medical and tropical departments at Minia University and general hospitals. Patient and methods: A convenient sample of 60 patients was included in this study. Data collected by interview questionnaire sheet which consists of three tools 1: patient's assessment sheet , tool 2: the designed nursing protocol, tool 3 the evaluation sheet. The results: Level of knowledge between both groups(study and control), it found that the majority of the study group was satisfactory level (56.7\%). There were highly statistical significant differences in relation to level of practice in both groups, the majority of the study group was (90\%) satisfactory level of practice, Conclusion: patient's knowledge skills related to ascites and how to minimize it's complications were improved after application of protocol than before. Recommendation: teaching and instructions in all hospitals directed toward importance of proper practice which dealing with complications of Ascites \& means of it's prevention.
\end{abstract}

Key words: Ascites, Liver Cirrhosis, Portal Hypertension, Esophageal Varices.

\section{Introduction}

Liver cirrhosis is a chronic, progressive disease of the liver it is characterized by degeneration and destruction of liver cells. Fibrotic bands of connective tissues impair the flow of blood and lymph and distort the normal liver structure (Lois et al., 2013).

The highest incidence of liver cirrhosis is in people between the ages 40 and 60 . It is the fifth leading cause of death for people in that age range in the United States. It is more common in men than women. The pathology is most often related to alcoholic - induced liver disease or chronic viral hepatitis (Linton, 2012).

The term ascites refer to marked increase in the volume of fluid in the peritoneal cavity. This is usually due to underlying disease in which the total body fluid is increased. (Nicole, et al., 2011).

The common problems and complications associated with hepatic cirrhosis depend on the amount of damage sustained by the liver. In compensated cirrhosis, the liver is scarred but can still perform essential function without causing major symptoms, In decompensated cirrhosis, liver function is impairedwith obvious manifestation of liver failure and loss of hepatic function contributes to development of metabolic abnormalities, hepatic cell damage may lead to these common complications; portal hypertention, bleeding esophageal varices, coagulation defects, jaundice, portal-systemic encephalopathy (PSE) with hepatic coma, hepatorenal syndrome, spontaneous bacterial pritonities and ascites (Ignatavicius, 2010).

Nursing assessment and intervention for ascites directed toward restoring normal fluid volume, improving gas exchange, maintaining skin integrity, measuring neurological state, improving nutritional state, infection prevention, improving self concept and restoring normal vital signs (Black \& Hawks, 2009).

A standard is a model of established practice that is commonly accepted as correct. The care provided by nurses is guided by standards of care. Standards of care were developed and implemented to define the quality of care provided. They are the basis for nursing care and draw on the latest scientific data from nursing literature. Clinical, administrative and academic experts have contributed to the development of standards of nursing practice. All standards of practice provide a guide to the Knowledge, skills, judgment and attitudes that are needed to practice safely (Dianne, 2010), 


\section{The Aim of the Study}

- The aim of this study is to identify the effect of implementing designed nursing protocol on minimizing complications of ascites among liver cirrhosis patients .

Patients and Methods

Research design: Quasi-Experimental research design was utilized

Setting: The study was conducted in the medical and tropical units at Minia university and general hospital.

Sample: A sample of convenience including cirrhotic ascites patients (60) in selected area.

Tools:

Tool I: Tool (1): Pre/post interview questionnaire sheet

This tool was used for pre- and post protocol implementation this tool is an interview questionnaire sheet constructed by the researcher after reviewing the related literatures. This tool included the following parts

\section{Part 1: - Socio demographic Data}

This part comprised patient's about the patient such as: patient's name, age, sex, level of education, occupation, marital status, address, duration of the disease, and residence.

Part 2: -Assessment of patient's physical condition

- This part includes: The patient's Medical diagnosis, patient's weight, abdominal circumference or girth, degree of ascites, activity level (Activity of Daily living "Barthel scale"), vital signs recording chart, diet and fluid intake, skin condition, level of Performance checklist for different procedures such as how to measure abdominal girth (mild, moderate, sever).

Tool II: Designed Nursing Protocol it was designed by the researcher after reviewing of literature to be implemented and applicated on the study group .

Tool III: Evaluation Tool This tool was developed to identify the effect of the designed nursing protocol on ascites problems. It include performance checklist to facilitate the evaluation , and the items of the checklist such as (measuring abdominal girth, measuring abdominal weight, care before ,during and after Paracentesis).

\section{Methods}

The study was executed on two phases:

\section{Phase (1): Assessment Phase}

In this phase, the tools for data collection after reviewing the related literature were developed. By the end of this phase, a pilot study was carried out on $10 \%$ of sample to test the feasibility of the study and applicability of the tools , and the time needed to complete the tool was 30-45 minutes. After pilot study, the tool was used.

\section{Phase (2): Planning Or Preparatory Phase}

An official permission was attained from head of the internal medicine department to conduct this study. The aim of the study and procedures was explained to them to attain their cooperation The nursing care protocol plan was developed and revised by expertise .

Phase (3): Implementation Phase

Oral or written consent is obtained from the patients : This phase lasted for 6 months from the time the study from december 2011to july 2012 , study and control groups were interviewed to obtain the required data to fill the patient's assessment sheet and patient's evaluation sheet. The control group received only unit routine nursing care, while the study group received the nursing care protocol and was teach to the patients through six (6) sessions all over the week. The sessions were organized in the morning and afternoon shifts each session was nearly 2 hours, as shown in session plane. 


\begin{tabular}{|c|c|c|c|c|}
\hline Sessions & $\begin{array}{c}\text { General } \\
\text { objectives }\end{array}$ & $\begin{array}{c}\text { Specific } \\
\text { Objectives }\end{array}$ & $\begin{array}{l}\text { Methods of teaching } \\
\text { and media used }\end{array}$ & Time \\
\hline $\begin{array}{l}\text { 1-Introduction a bout } \\
\text { liver (anatomy, } \\
\text { functions, liver } \\
\text { cirrhosis, and its } \\
\text { complications. }\end{array}$ & $\begin{array}{l}\text {-To increase } \\
\text { patient } \\
\text { knowledge } \\
\text { about liver and } \\
\text { its } \\
\text { complications. }\end{array}$ & $\begin{array}{l}\text { - Patient knows what are } \\
\text { the liver and its location, } \\
\text { functions. } \\
\text { - Patient will be } \\
\text { knowledgeable about the } \\
\text { liver cirrhosis and its } \\
\text { causes, incidence, } \\
\text { complications }\end{array}$ & $\begin{array}{l}\text { - Lecture. } \\
\text { - posters } \\
\text { - simulation }\end{array}$ & 2 hours \\
\hline $\begin{array}{l}\text { 2- Ascites (definitions, } \\
\text { degree, signs and } \\
\text { symptoms. }\end{array}$ & $\begin{array}{l}\text { - To increase } \\
\text { patient } \\
\text { knowledge } \\
\text { about ascites and } \\
\text { its complications }\end{array}$ & $\begin{array}{l}\text { - Patient knows } \\
\text { definition of ascites, } \\
\text { degrees or grades, its } \\
\text { signs, symptoms and } \\
\text { complications. }\end{array}$ & $\begin{array}{l}\text { - Posters. } \\
\text {-Lecture. }\end{array}$ & 2 hours \\
\hline $\begin{array}{l}\text { 3- How to measure } \\
\text { abdominal } \\
\text { circumference or girth. }\end{array}$ & $\begin{array}{l}\text { - To make the } \\
\text { patient able to } \\
\text { measure } \\
\text { abdominal } \\
\text { circumference }\end{array}$ & $\begin{array}{l}\text {-Increase patient practice } \\
\text { of measuring abdominal } \\
\text { girth. } \\
\text { - Patient will be able to } \\
\text { evaluate his condition }\end{array}$ & $\begin{array}{l}\text {-posters } \\
\text { - simulation } \\
\text { - Lecture }\end{array}$ & 2 hours \\
\hline $\begin{array}{l}\text { 4- How to measure his } \\
\text { body weight. }\end{array}$ & $\begin{array}{l}\text { - To make the } \\
\text { patient able to } \\
\text { measure his or } \\
\text { her body weight }\end{array}$ & $\begin{array}{l}\text { - To Increase patient } \\
\text { practice of measuring } \\
\text { body weight. } \\
\text { - Patient will be able to } \\
\text { evaluate his condition } \\
\text { through weight gain or } \\
\text { loss. }\end{array}$ & $\begin{array}{l}\text { - posters } \\
\text { - simulation } \\
\text { - Lectures }\end{array}$ & 2 hours \\
\hline $\begin{array}{l}\text { 5- How to perform } \\
\text { coughing and breathing } \\
\text { exercises. }\end{array}$ & $\begin{array}{l}\text { - To make the } \\
\text { patient able to } \\
\text { perform } \\
\text { breathing and } \\
\text { coughing } \\
\text { exercises. }\end{array}$ & $\begin{array}{l}\text { - Patient will be able to } \\
\text { perform abdominal } \\
\text { breathing exercise, deep } \\
\text { breathing, deep } \\
\text { breathing and coughing } \\
\text { exercises. } \\
\text { - To alleviate dyspnea }\end{array}$ & $\begin{array}{l}\text { - Demonstrator. } \\
\text {-Lectures. } \\
\text { - Posters. }\end{array}$ & 2 hours \\
\hline $\begin{array}{l}\text { 6- How to manage and } \\
\text { overcome the } \\
\text { complications of ascites. }\end{array}$ & $\begin{array}{l}\text { - To make the } \\
\text { patient able to } \\
\text { manage the } \\
\text { ascites } \\
\text { complicatitions }\end{array}$ & $\begin{array}{l}\text {-To alleviate dyspnea } \\
\text {-To prevent herniation - } \\
\text { To prevent peritonitis. } \\
\text { - To establish fluid and } \\
\text { electrolyte balance. } \\
\text { - To avoid } \\
\text { Gastrointestinal } \\
\text { elimination problems }\end{array}$ & $\begin{array}{l}\text { - Posters } \\
\text { - Lectures }\end{array}$ & 2 hours \\
\hline
\end{tabular}

\section{Data analysis}

The statistical analysis was carried out using SPSS 16.0. The collected data were tabulated and analyzed by using frequency distribution, percentage, mean, range and standard deviation. The level of significance was considered at $5 \%$ level $(\mathrm{P}=0.05)$. $\mathrm{T}$ test was used to determine the differences between the knowledge and practice in relation to sociodemographic characteristics of patients . Pearson-moment product correlation coefficient was used to find out the relationship between total knowledge and practice. 


\section{Results}

Frequency distribution of socio demographic characteristics of patients showed that, most of the Shows that the majority of the study sample was males, as regard occupation most of the study group was not working and illiterated. As regard residence the majority of the study and control were rural.

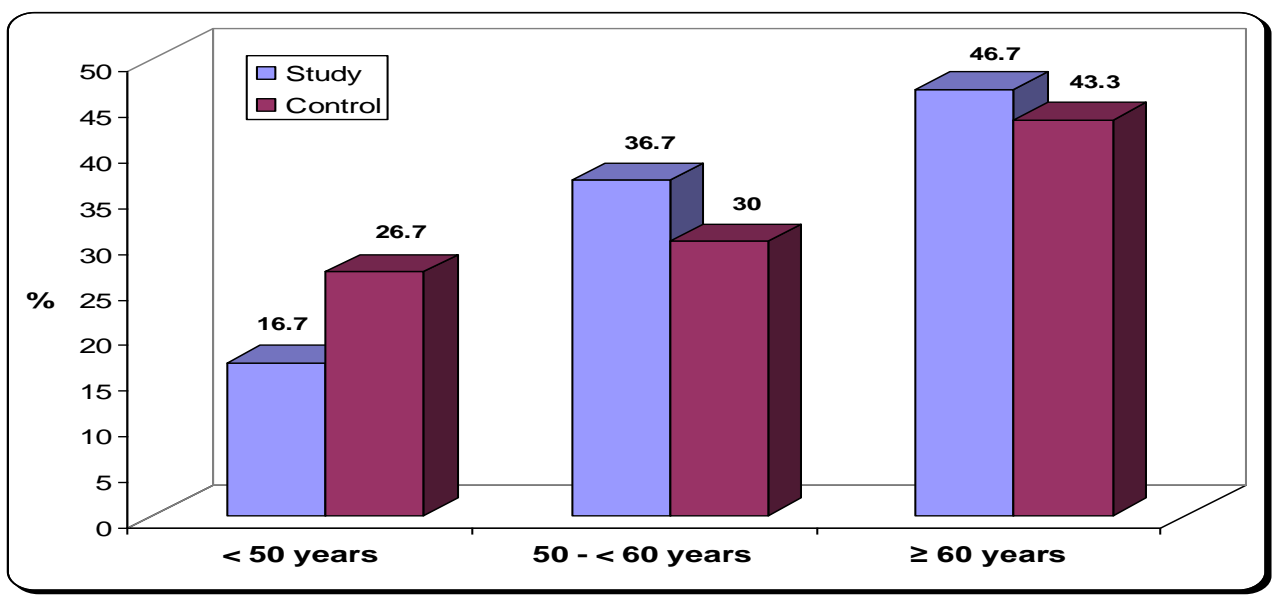

Fig. (1): Age distribution

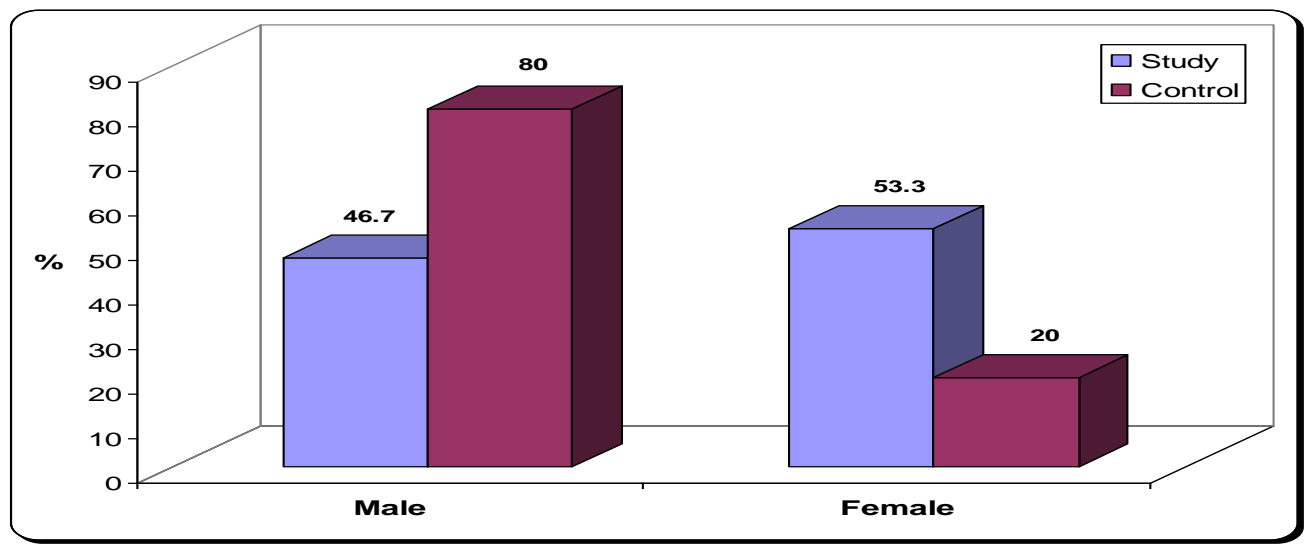

Fig. (2): Sex distribution

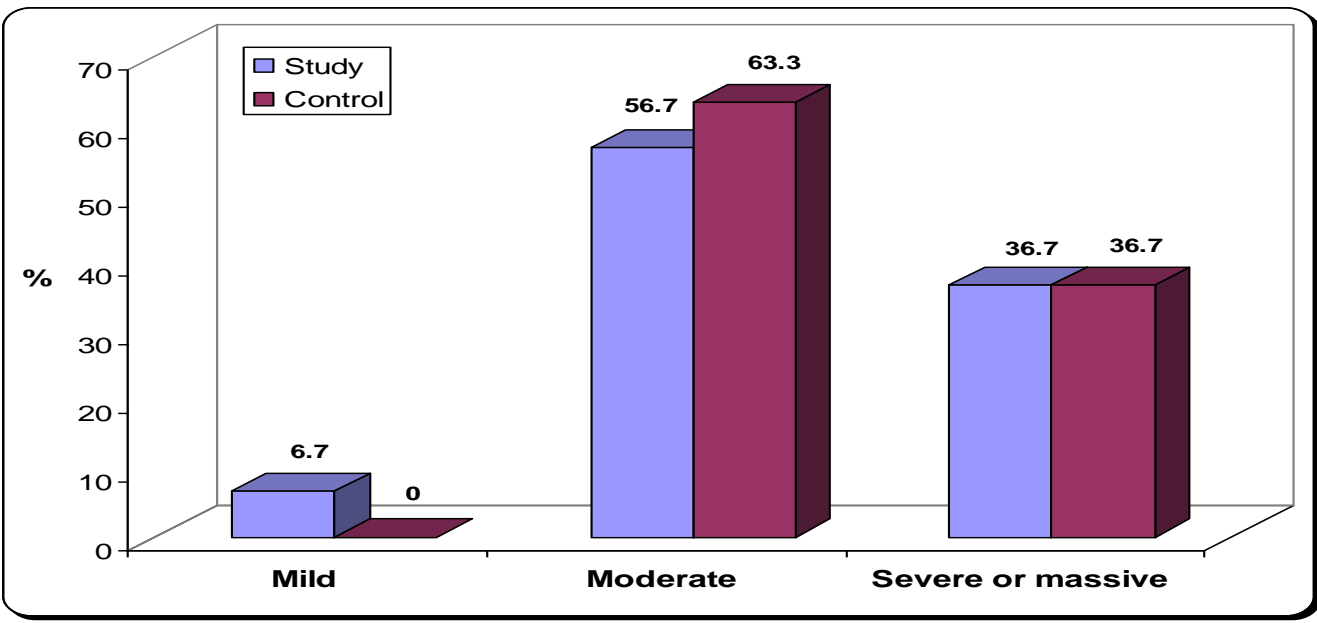

Fig. (3): Ascites degree in study and control groups 
Table (1): Distribution of the study sample related to physical assessment and vital signs.

\begin{tabular}{|l|c|c|c|}
\hline \multicolumn{1}{|c|}{ Variables } & Study $(\mathbf{n}=\mathbf{3 0})$ & Control $(\mathbf{n}=\mathbf{3 0})$ & \multirow{2}{*}{ Pvalue } \\
\cline { 2 - 3 } & Mean $\mathbf{\text { SD }}$ & Mean \pm SD & \\
\hline Abdominal girth(cm) & $101.50 \pm 9.93$ & $103.48 \pm 11.94$ & 0.487 \\
\hline Patient weight(kg) & $69.17 \pm 10.02$ & $76.10 \pm 7.33$ & $0.003^{*}$ \\
\hline Body temperature(Ć) & $37.06 \pm 0.65$ & $37.37 \pm 0.39$ & $0.027^{*}$ \\
\hline Pulse(b/m) & $87.43 \pm 9.41$ & $83.90 \pm 11.57$ & 0.200 \\
\hline Respiration(C/m) & $19.90 \pm 1.52$ & $21.60 \pm 2.18$ & $0.001^{*}$ \\
\hline Systolic BP $(\mathbf{m m h g})$ & $112.67 \pm 15.07$ & $116.33 \pm 18.43$ & 0.402 \\
\hline Diastolic BP(mmhg) & $61.17 \pm 11.65$ & $71.50 \pm 15.71$ & $0.005^{*}$ \\
\hline
\end{tabular}

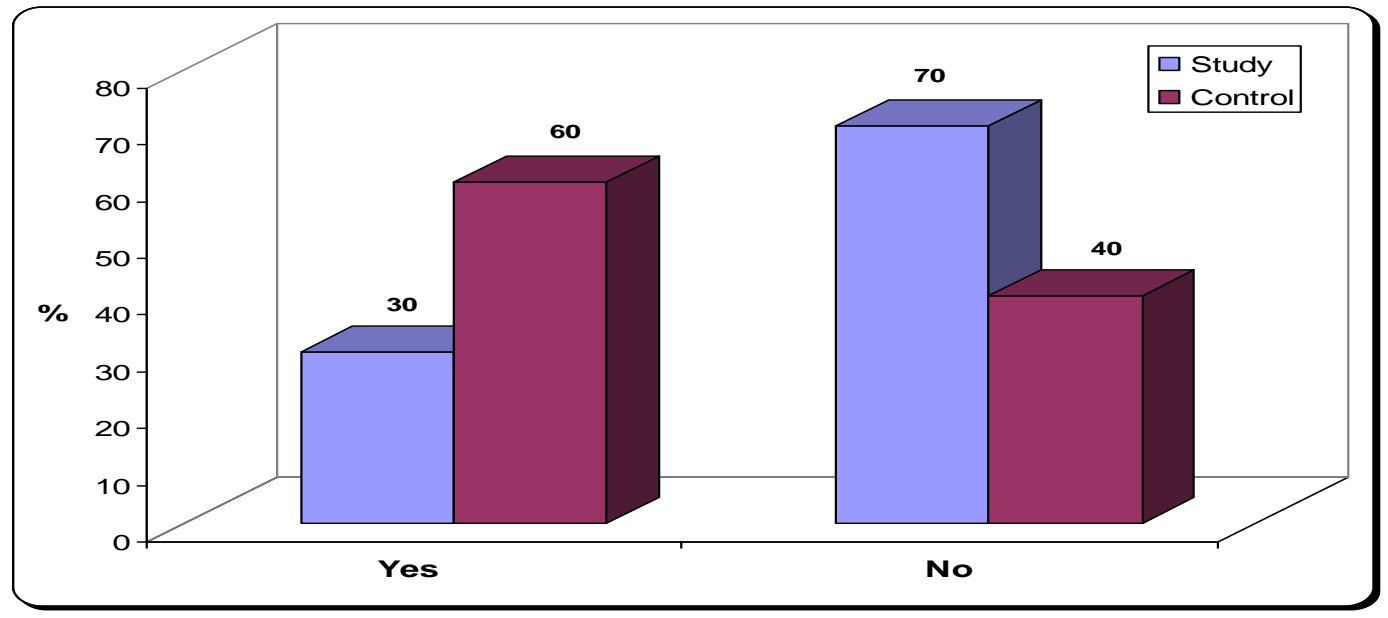

Fig. (4): distribution of Peritonitis in study and control groups

Table (2): Distribution of the study sample in relation to ascites care.

\begin{tabular}{|l|c|c|c|c|c|}
\hline \multirow{2}{*}{ Variables } & \multicolumn{2}{|c|}{ Study } & \multicolumn{2}{c|}{ Control } & \multirow{2}{*}{ P-value } \\
\cline { 2 - 5 } & No. & \% & No. & \% & \\
\hline Therapeutic diet & 10 & 33.3 & 0 & 0.0 & $0.001^{*}$ \\
\hline Administration of diuretics & 7 & 23.3 & 29 & 96.7 & $0.000^{*}$ \\
\hline Elevated the head of the bed 45 degree & 26 & 86.7 & 0 & 0.0 & $0.000^{*}$ \\
\hline Wear abdominal belt & 6 & 20.0 & 2 & 6.7 & 0.129 \\
\hline Paracentesis & 6 & 20.0 & 25 & 83.3 & $0.000^{*}$ \\
\hline Albumin administration & 3 & 10.0 & 29 & 96.7 & $0.000^{*}$ \\
\hline Avoid spicy food & 30 & 100.0 & 1 & 3.3 & $0.000^{*}$ \\
\hline Change position during sleep & 21 & 70.0 & 12 & 40.0 & $0.020^{*}$ \\
\hline
\end{tabular}

Table (3): Distribution of the study sample related to dyspnea and skin care .

\begin{tabular}{|c|c|c|c|c|c|}
\hline \multirow{2}{*}{ Variables } & \multicolumn{2}{|c|}{ Study } & \multicolumn{2}{|c|}{ Control } & \multirow{2}{*}{ P-value } \\
\hline & No. & $\%$ & No. & $\%$ & \\
\hline \multicolumn{6}{|l|}{ Dyspnea care } \\
\hline Elevated the head of the bed 30 degree & 26 & 86.7 & 1 & 3.3 & $0.000^{*}$ \\
\hline $\begin{array}{l}\text { Perform breathing exercises to improve } \\
\text { breathing }\end{array}$ & 27 & 90.0 & 0 & 0.0 & $0.000^{*}$ \\
\hline Drink warm fluids & 10 & 33.3 & 0 & 0.0 & $0.001 *$ \\
\hline Change position frequently & 2 & 6.7 & 23 & 76.7 & $0.000^{*}$ \\
\hline None & 1 & 3.3 & 7 & 23.3 & $0.023^{*}$ \\
\hline
\end{tabular}




\begin{tabular}{|c|c|c|c|c|c|}
\hline \multirow{2}{*}{ Variables } & \multicolumn{2}{|c|}{ Study } & \multicolumn{2}{|c|}{ Control } & \multirow{2}{*}{ P-value } \\
\hline & No. & $\%$ & No. & $\%$ & \\
\hline \multicolumn{6}{|l|}{ Care of skin problems } \\
\hline Massage on affected parts & 1 & 3.3 & 1 & 3.3 & 1.000 \\
\hline Use of alcohol and powder & 1 & 3.3 & 0 & 0.0 & 0.313 \\
\hline Use of lubricants & 28 & 93.3 & 0 & 0.0 & $0.000^{*}$ \\
\hline Itching & 0 & 0.0 & 25 & 83.3 & $0.000^{*}$ \\
\hline None & 0 & 0.0 & 4 & 13.3 & $0.038^{*}$ \\
\hline
\end{tabular}

Table (4): Distribution of the study sample related to gastrointestinal symptoms.

\begin{tabular}{|c|c|c|c|c|c|}
\hline \multirow[b]{2}{*}{ Items } & \multicolumn{2}{|c|}{ Study $(n=30)$} & \multicolumn{2}{|c|}{ Control $(n=30)$} & \multirow{2}{*}{ P-value } \\
\hline & No. & $\%$ & No. & $\%$ & \\
\hline \multicolumn{6}{|l|}{ Stomach complain } \\
\hline Nausea & 15 & 50.0 & 25 & 83.3 & $0.007 *$ \\
\hline Vomiting & 4 & 13.3 & 5 & 16.7 & 0.760 \\
\hline Distention & 9 & 30.0 & 7 & 23.3 & 0.501 \\
\hline Pain & 1 & 3.3 & 2 & 6.7 & 0.574 \\
\hline Acidity and epigastric burning & 24 & 80.0 & 25 & 83.3 & 0.957 \\
\hline Feeling during eating & & & & & \multirow{4}{*}{1.000} \\
\hline Anorexia and discomfort & 29 & 96.7 & 29 & 96.7 & \\
\hline Dysphagia (difficult in swallowing) & 1 & 3.3 & 1 & 3.3 & \\
\hline Difficult in mastication & 0 & 0.0 & 0 & 0.0 & \\
\hline \multicolumn{5}{|l|}{ Status of appetite } & \multirow{4}{*}{0.438} \\
\hline Good & 3 & 10.0 & 1 & 3.3 & \\
\hline Fair & 12 & 40.0 & 10 & 33.3 & \\
\hline Poor & 15 & 50.0 & 19 & 63.3 & \\
\hline \multicolumn{6}{|l|}{ Intestinal complains } \\
\hline Diarrhea & 12 & 40.0 & 11 & 36.7 & 0.791 \\
\hline Diarrhea \& constipation & 3 & 10.0 & 1 & 3.3 & 0.301 \\
\hline Constipation & 5 & 16.7 & 11 & 36.7 & 0.080 \\
\hline Pain during defecation & 0 & 0.0 & 0 & 0.0 & -- \\
\hline Piles or hemorried & 0 & 0.0 & 0 & 0.0 & -- \\
\hline None & 10 & 33.3 & 7 & 23.3 & 0.390 \\
\hline
\end{tabular}

Table (5): Distribution of the study sample related to activity daily living (Barthel scale).

\begin{tabular}{|c|c|c|c|c|c|c|c|c|c|c|c|c|c|}
\hline \multirow{3}{*}{ Items } & \multicolumn{6}{|c|}{ Study } & \multicolumn{6}{|c|}{ Control } & \multirow{3}{*}{ P-value } \\
\hline & \multicolumn{2}{|c|}{ Able } & \multicolumn{2}{|c|}{ Need assist } & \multicolumn{2}{|c|}{ Not able } & \multicolumn{2}{|c|}{ Able } & \multicolumn{2}{|c|}{ Need assist } & \multicolumn{2}{|c|}{ Not able } & \\
\hline & No. & $\%$ & No. & $\%$ & No. & $\%$ & No. & $\%$ & No. & $\%$ & No. & $\%$ & \\
\hline Bladder control & 29 & 96.7 & 1 & 3.3 & 0 & 0.0 & 29 & 96.7 & 1 & 3.3 & 0 & 0.0 & 1.000 \\
\hline Bowels control & 29 & 96.7 & 1 & 3.3 & 0 & 0.0 & 29 & 96.7 & 1 & 3.3 & 0 & 0.0 & 1.000 \\
\hline Grooming & 25 & 83.3 & 5 & 16.7 & 0 & 0.0 & 3 & 10.0 & 27 & 90.0 & 0 & 0.0 & $0.000 *$ \\
\hline Personal toilet & 22 & 73.3 & 7 & 23.3 & 1 & 3.3 & 2 & 6.7 & 28 & 93.3 & 0 & 0.0 & $0.000 *$ \\
\hline Bathing self & 10 & 33.3 & 19 & 63.3 & 1 & 3.3 & 1 & 3.3 & 28 & 93.3 & 1 & 3.3 & $0.011 *$ \\
\hline Feeding & 25 & 83.3 & 5 & 16.7 & 0 & 0.0 & 3 & 10.0 & 26 & 86.7 & 1 & 3.3 & $0.000 *$ \\
\hline Transferring & 0 & 0.0 & 14 & 46.7 & 16 & 53.3 & 1 & 3.3 & 23 & 76.7 & 6 & 20.0 & $0.021 *$ \\
\hline Mobility & 3 & 10.0 & 13 & 43.3 & 14 & 46.7 & 0 & 0.0 & 25 & 83.3 & 5 & 16.7 & $0.004 *$ \\
\hline Use of Stairs & 0 & 0.0 & 13 & 43.3 & 17 & 56.7 & 0 & 0.0 & 22 & 73.3 & 8 & 26.7 & $0.018 *$ \\
\hline Dressing & 4 & 13.3 & 22 & 73.3 & 4 & 13.3 & 1 & 3.3 & 24 & 80.0 & 5 & 16.7 & 0.368 \\
\hline
\end{tabular}




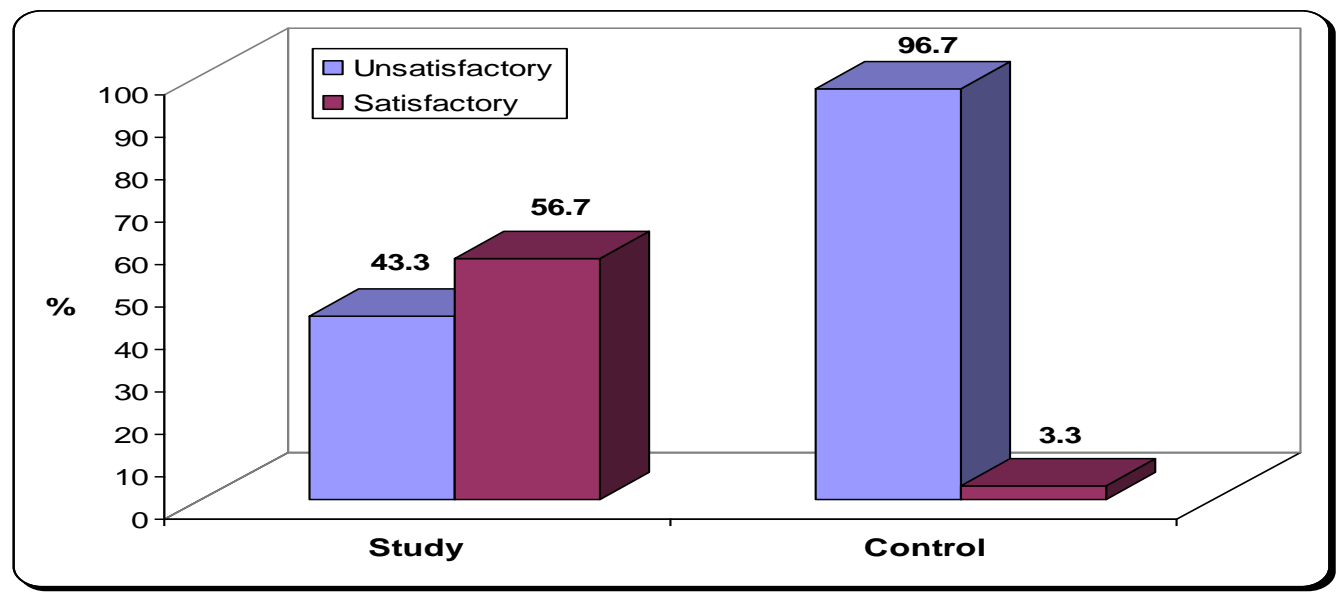

Fig. (5): Distribution the Level of knowledge in study (Post) and control groups

Table (6): Distribution of the study group pre and post protocol related to Level of practices .

\begin{tabular}{|l|c|c|c|c|}
\hline \multirow{2}{*}{ Practices } & \multicolumn{2}{|c|}{ Pre (n= 30) } & \multicolumn{2}{c|}{ Post (n= 30) } \\
\cline { 2 - 5 } & No. & \% & No. & \% \\
\hline Unsatisfactory & 30 & 100.0 & 3 & 10.0 \\
\hline Satisfactory & 0 & 0.0 & 27 & 90.0 \\
\hline P-value & \multicolumn{2}{|c|}{$0.000^{*}$} \\
\hline
\end{tabular}

Table (7): Correlation between knowledge and personal characteristics of age and sex

\begin{tabular}{|c|c|c|}
\hline & Score of knowledge & \multirow{2}{*}{ P-value } \\
\hline & Mean \pm SD & \\
\hline \multicolumn{2}{|l|}{ Age } & \multirow{4}{*}{0.107} \\
\hline$<50$ & $6.60 \pm 1.34$ & \\
\hline $50-<60$ & $5.09 \pm 1.22$ & \\
\hline$\geq 60$ & $5.93 \pm 1.44$ & \\
\hline Sex & & \multirow{3}{*}{0.226} \\
\hline Male & $6.07 \pm 1.38$ & \\
\hline Female & $5.44 \pm 1.41$ & \\
\hline
\end{tabular}

Mean $\pm S D \quad(6.07 \pm 1.38)$

Table (8): Correlation between practices and personal characteristics (age -sex)

\begin{tabular}{|c|c|c|}
\hline & Score of practices & \multirow{2}{*}{ P-value } \\
\hline & Mean \pm SD & \\
\hline \multicolumn{2}{|l|}{ Age } & \multirow{4}{*}{0.540} \\
\hline$<50$ & $18.20 \pm 5.97$ & \\
\hline $50-<60$ & $16.64 \pm 7.15$ & \\
\hline$\geq 60$ & $19.43 \pm 5.37$ & \\
\hline Sex: & & \\
\hline Male & $18.71 \pm 5.68$ & 0.673 \\
\hline Female & $17.75 \pm 6.59$ & \\
\hline
\end{tabular}

Fig. (1): this figure shows the age distribution the study and control groups.

Fig. (2):this figure shows the sex distribution among the study sample (study-control group).
Fig. (3):shows the ascites degree in the study and control group. 
Table (1): The table illustrated the distribution of study and control group related to physical assessment and vital signs .

Fig. (4):shows the distribution of peritonitis in the study and control groups.

Table (2): The table illustrated the distribution of study and control group in relation to ascites care.

Table (3): This table demonstrated that there were highly statistical significant differences in the study and control groups in all items of dyspnea and skin problems, except in two items in care of skin problems (Message on affected parts, Use of alcohol and powder).

Table (4): The table demonstrates that there was no statistical significant differences between study and control groups in all items of GIT symptoms except in one item (Nausea).

Table (5): this table illustrated that activity daily living (Barthel scale) in study and control groups, it found that there were statistical significant differences in all its items, except in relation to the other items (bladder control, bowel control, and dressing).

Fig. (5) : shows the level of knowledge in the study and control groups .

Table (6): The table illustrated the Level of practices in the study groups in relation to level of practice and the result revealed that the majority of the post $(90.0 \%)$ was satisfactory.

Table (7): This table shows that the patients who their age group less than 50years are more knowledgeable by mean and standard deviation of Mean \pm SD $(6.60 \pm 1.34)$, and as regard sex the male are more knowledgeable than female by mean and standard deviation of Mean \pm SD .

Table (8): This table illustrated the mean and standard deviation of age and sex regard level of practices, there was the patients whose age group $\geq 60$ have highest score of practice with mean and standard deviation $(19.43 \pm 5.37)$, and as regard sex, male patients have highest score of practice with mean and standard deviation of $(18.71 \pm 5.68)$

\section{Discussion}

Ascites is one of the major complication of liver cirrhosis and portal hypertension. Within 10 years of the diagnosis of cirrhosis, more than $50 \%$ of patients develops ascites. The development of ascites is associated with a poor prognosis, with a mortality of $15 \%$ at one- year and $44 \%$ at five years follow- up ,respectively.therefore patients with ascites should be considered for liver transplantation planas, et al., (2006).

The aim of this study is to identify the effect of implementing designed nursing protocol on minimizing complications of ascites among liver cirrhosis Based on the results of present study; the majority of the patients were males in middle adulthood, that is characteristically a life stage of work and productions. This finding supported by Abd el Ghaffar, (2004), who reported that the percentage of liver cirrhosis is higher among male patients than female patients in Egypt.

In the same line with the current study finding which, mentioned that; liver cirrhosis is as twice as common in men than in women and is especially prevalent among malnourished patients over age 50 years of age. Gines, (2005) \& linton, (2012).

The results of the current study represented that; about more than half of the study patients were illiterates, this would be attributed to the fact that the majority of the study patients was residing in rural areas. These finding are consistent with Sallam, (2007) who reported that; most of the study patients were illiterate. According to the study which was carried out by Vanderplas et al., (2003), on a number of cirrhotic liver patients, it revealed that the majority of the sample had secondary education, this result disagree with the

The result of the present study revealed that there are statistical significant differences in relation to dyspnea and ineffective breathing pattern and nausea and this complications improved in the study group , and this is supported by Bouldoff, (2006) who stated that ascetic fluid can cause the abdomen to become greatly distended. While in bed the patient breathes easier with the head of the bed elevated. Sitting in a chair with the feet elevated.

The current study revealed that the minority of patients with liver cirrhosis and ascites suffering from Spontaneous bacterial peritonitis (SBP), and this supported by a result of an study included 100 patients minority of them had spontaneous bacterial infection and majority have no spontaneous bacterial infection and majority of the patients in the study were in the age range of 46-55 years, the mean age was 54 years and the median age was 52 years Zahidullah khan, et al ., (2009).

In the current study revealed that there are Statistically Significant differences between both groups in relation to peritonitis symptoms which were abdominal pain then abdominal tenderness and this is was supported by an study result that the more common presenting symptoms were abdominal pain then abdominal tenderness, fever, jaundice, hepatic encephalopathy and hypotension patients were asymptomatic. nearly the same result was observed in one other local study Imran, (2006), 


\section{Conclusion}

Based on the results of the present study, patient's knowledge and skills related to ascites and how to minimize complications of ascites were improved after application of designed nursing protocol than before, it found that the majority of the study group was satisfactory level, and regard unsatisfactory level of knowledge ,it decreased in the study group . The majority of patients with decompensate liver cirrhosis with ascites develop ascites complications, uncomplicated ascites such as the mild and moderate degree of ascites, response to the guidelines of the nursing protocol which applied and the result become significant with them.

\section{Recommendations}

Based on the finding of this study, following recommendations were made

- Teaching and instructions should be an integral part of the nurse's duty in all hospitals. And should be directed toward importance and proper practice which dealing with complications of Ascites, means of prevention of complications .

- Establishment of health education program in medical and tropical departments for cirrhotic ascites patients, using posters, illustrated pamphlets, models, simulators, videos taps for patients with cirrhotic ascites .

- Ascites club should be constructed in Egypt as the international ascites club because the incidence and prevalence of liver cirrhosis and ascites become increased in our local area and all over Egypt.

- There should be collaboration specialties, restricted, firm supervision within each hospital regard the

- ascites care .And hospital should increase its supplies and facilities to attain high quality of care and positive expected out com.

- Improve the administration process of the hospital to maintain more accurate and secured patient data.

\section{References}

1. Abdel Ghaffar, Y., (2004): Hematology in Egypt 20 years ago, cirrhosis in Egypt, The Afro- Arab liver journal, 3 (1), pp. 33-58.

2. Bouldoff G., Plaz, P., (2006): Improving out comes for COPD patients. The nurses practitioner 31(8)pp 26-43.

3. Cesario, K., Choure, A., \& Carey, W., (2011): Complications oCirrhosis: ascites, Hepatic Encephalopathy, and Variceal Hemorrhage, (C) 2000-2011, the Cleveland Clinic Foundation, Center for Continuing
4. Imran M., Hashmi S., Altaf A., Rashid H., Hussain. T., (2006): Spontaneous Bacterial Peritonitis. Professional Med J Jun; 13:pp 201205

5. Lewis, Dirksen, Heitkemper, Buchcher, Camera, (2011): Medical surgical nursing ,Assessment and management of clinical problems , ch (44):nursing management of liver, pancreas and biliary tract problems section (8) problems of ingestion, digestion, absorption and elimination $\mathrm{pp}(1058-1102)$

6. Lewis, S., Cohin, I., \& Heilkemper, M., (2007): Medical Surgical Nursing: Asessment and Management of clinical problems. (4th) ed. London: Mosby ()

7. Linton Adrianne Dill., (2012): introduction to Medical - surgical Nursing, 5Ed, unit (10) Digestive Disorders, ch (39): Disorders of the liver, Gallbladder, pancrease pp850-859.

8. Nicol M., Brooker C., (2011): Alexander nursing practice, Nursing patient with gastrointestinal liver and biliary disorders, $4 \mathrm{Ed}$ ch. 4, pp104-110.

9. Planas R., Montoliu S., Balleste b,Rivera M., Miquel MasnouH, Galeras J., Gimenez M., Santos J., Cirera I., Morillas R., Coll S,Sola R., (2006): Natural history of patient hospitalized for management of cirrhotic ascites . Clin Gastroenterol Hepatol; ( 4) :pp. 13851394.

10. Runyon B., (2006): Ascites and spontaneous bacterial peritonitis. In: Feldman M, Friedman LS, Brandt LJ, eds. Sleisenger and Fordtran's Gastrointestinal and Liver Disease. 8th ed. Philadelphia, PA: Saunders;:pp 1935-1964.

11. Sallam, I., (2007): The role of parenteral antischistosomal therapy in the spread of HCV in Egypt, available at: http://www.PubMed.com

12. Vanderplas, S., Iiansen, B., De Boer, J., Stijnen, T., Passo, J., De man, R., \& Schalm, S., (2003): Generic and disease - specific health related quality of life in non-cirrhotic, cirrhotic, and transplanted liver pts, available at: http: //www.Medicine,Come.

13. Zahidulla Khan., (2009): Gomal Journal of medical sciences, July - Decemper vol.7, No . 2.

14. Runyon, B., (2009): Management of adult patient with ascites due to cirrhosis, an up date "Hepatology". Vol. 49, No 6. 